\title{
Working
}

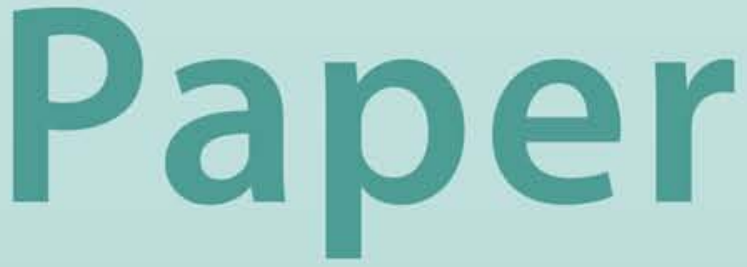


The Electricity Sector in FYR Macedonia

Alexander F. Tieman 


\title{
IMF Working Paper
}

European Department

\section{The Electricity Sector in FYR Macedonia}

Prepared by Alexander F. Tieman ${ }^{1}$

Authorized for distribution by Wesley McGrew

February 2011

\begin{abstract}
This paper describes the current state of the Macedonian electricity sector. It looks at ongoing structural changes, driven by the gradual adoption of the EU acquis on energy, and comes up with estimates for electricity subsidies. It concludes by discussing the longer term outlook and sketching policy options.

JEL Classification Numbers: I38, L3, L5, L94, L98, Q43, Q48

Keywords: Electricity, FYR Macedonia, Liberalization, Subsidies, EU acquis, ECT

Author’s E-Mail Address: atieman@imf.org
\end{abstract}

\section{This Working Paper should not be reported as representing the views of the IMF.}

The views expressed in this Working Paper are those of the author(s) and do not necessarily represent those of the IMF or IMF policy. Working Papers describe research in progress by the author(s) and are published to elicit comments and to further debate.

\footnotetext{
${ }^{1}$ This work has benefitted from discussion with many stakeholders in Macedonia, as well as comments from World Bank staff and Daniel-Alexander Schroth of the EU Delegation in Skopje. The author would like to thank them all.
} 


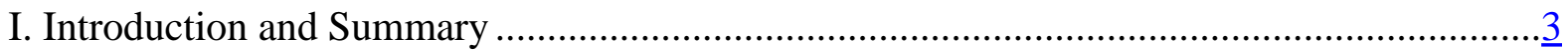

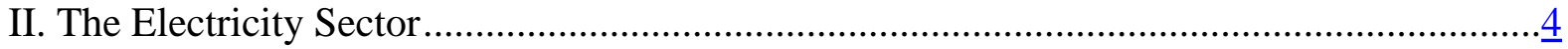

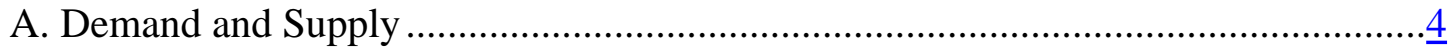

B. Market Structure ..........................................................................................

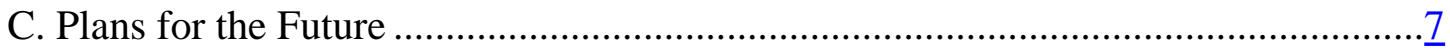

III. European Integration is Driving Electricity Reform................................................. $\underline{8}$

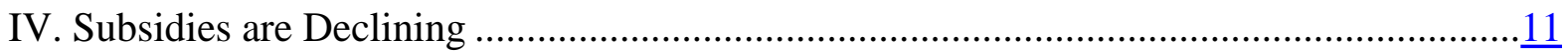

V. Longer Term Outlook and Policy Options..............................................................15

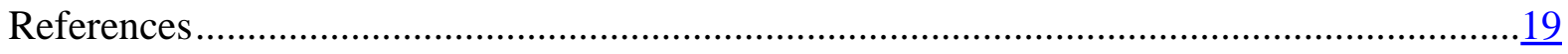

Tables

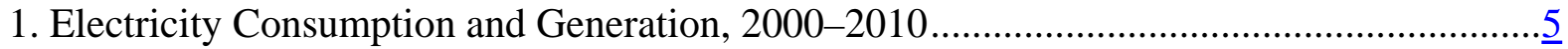

2. Subsidies and Losses in the Electricity Sector, 2008-2010 ..........................................12

3. Subsidies and Losses in the Electricity Sector, Scenarios for 2015 .................................14

Figures

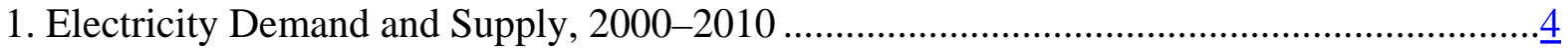




\section{INTRODUCTION AND SUMMARY}

The Macedonian energy sector is in a transitional phase from centrally planned and managed to a decentralized regulated free market. Like in many of its peers in the region, the energy sector is still working to overcome its collectivist legacy. On the demand side, the key challenge is to improve efficiency of energy usage, which has been held back by below market pricing for all but the largest users. On the supply side, challenges include the limited range of options for energy supply, due to Macedonia's lack of oil, gas or high quality coal reserves, and ageing generation facilities. These factors have resulted in a shortage of domestic generation capacity, as well as relatively inefficient and dirty facilities.

In order to sustain economic growth over the medium-to long-term, Macedonia would have to address both demand and supply issues. New investment in generation should be done based on least-cost analyses, taking into account environmental standards. The rise in demand should be moderated by promoting energy efficiency measures, as well as market liberalization and the concomitant price increases. In order to create the right incentives on both sides of the market, establishing an efficient energy market is crucial. This will imply further sector reform, including legislation and regulation.

Recent reforms are helping to address these issues, and the country is committed to further reforms, that will bring about full liberalization of the energy market.

Macedonia has signed the Energy Community Treaty (ECT), which commits the signatories to implement the relevant parts of the EU acquis communautaire. In particular, the signatories aim to set up a single regional stable regulatory market framework capable of attracting investment in transmission networks and generation capacity, and fostering competition and interconnectivity, thus ensuring supply and realizing economies of scale. The government has recently drafted a new Energy Law, which, once fully implemented together with the necessary secondary legislation, is expected to bring the country in compliance with its Treaty obligations.

Past structural reform of the electricity sector is already paying off. Implicit electricity pricing subsidies have steadily decreased from 3.8 percent of GDP in 2008 to 0.7 percent of GDP in 2010. This is mainly on the back of lower regional energy prices and increases in the domestic price for subsidized end-users, and the full liberalization of the market for the 10 largest users. In addition, the privatization of distribution in 2006, and the subsequent substantial investment by the new owner, has reduced distribution losses and collection shortfalls.

Going forward, Macedonia's challenge will be to implement fully its reform plans, which are needed to boost supply while containing demand. Implementation of the new Energy Law will result in full electricity market liberalization by 2015, which, together with providing a stable and predictable legal and regulatory environment, is essential for attracting large-scale long-term private sector investment in generation capacity. Market-based pricing, the promotion of energy awareness among users, including attention for insulation of homes and businesses, and further attention to collection enforcement, will contain increases in demand. Gasification of the country can also contribute to lowering energy demand and 
increasing supply, as natural gas provides a more efficient option for heating buildings, and a denser gas network provides incentives to increase electricity supply by making relatively environmentally-friendly cogeneration combined heat and power plants more attractive to build. Taken together, these energy policies should ensure the security of supply, and hence provide a necessary precondition for economic growth over the medium to long-term.

Energy reform will also have a favorable macroeconomic impact. Liberalized prices and private investment will help ensure the sector does not become a fiscal burden or a source of balance of payments pressures (as in 2008, when a spike in import prices coupled with a drop in domestic output caused the value of imports to surge). Furthermore, in a liberalized environment, subsidy outlays can be reduced and cover social assistance to the poorest households only.

\section{THE ELECTRICITY SECTOR}

\section{A. Demand and Supply}

Over the past decade, supply has failed to keep up with demand, despite modest improvements in energy efficiency. Between 2000 and 2008, energy consumption rose 34 percent, from 6,433 GWh to 8,609 GWh (Figure 1 and Table 1). In 2009, consumption decreased to 7,597 GWh, on the back of a collapse of (electricity-intensive) exports from heavy industry. Including this slump, demand growth averaged 1.9 percent per year between 2000 and 2009, below GDP growth of 2.7 percent on average over the period, indicating that the energy intensity of production has increased. While demand has grown, domestic supply actually decreased from 6,326 GWh in 2000 to 6,152 GWh in 2009. The remainder of consumption, some 1,500 GWh annually on average, was met from imports, which cost an

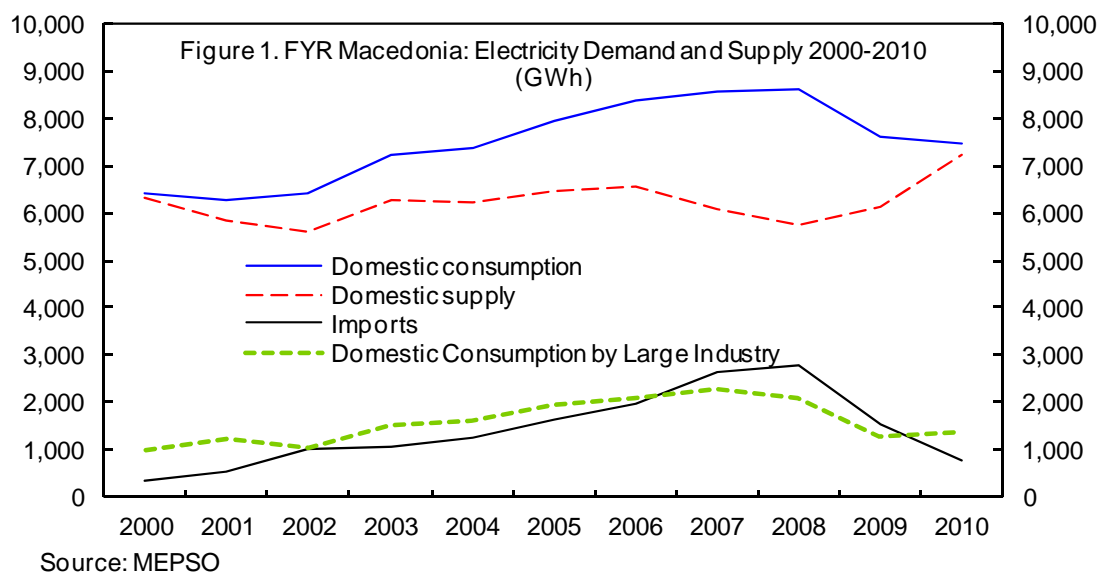
average of $€ 95$ million in the years 2003-09, and peaked at $€ 235$ million (or 3.6 percent of GDP) in 2008, adding substantially to the country's current account deficit. 


\begin{tabular}{|c|c|c|c|c|c|c|c|c|c|c|c|}
\hline & 2000 & 2001 & 2002 & 2003 & 2004 & 2005 & 2006 & 2007 & 2008 & 2009 & 2010 5/ \\
\hline \multicolumn{12}{|l|}{ Demand } \\
\hline Large Industry & 976 & 1198 & 1046 & 1531 & 1622 & 1937 & 2072 & 2281 & 2084 & 1284 & 1359 \\
\hline Households and SMES & 5246 & 4885 & 5170 & 5461 & 5571 & 5755 & 6062 & 6064 & 6251 & 6140 & 5913 \\
\hline of which: Techinical Losses and Theft $1 / 2 /$ & 820 & 870 & 1053 & 1083 & 1199 & 1316 & & & & & \\
\hline \multicolumn{12}{|l|}{ Supply } \\
\hline Domestic supply & 6326 & 5863 & 5619 & 6273 & 6208 & 6474 & 6568 & 6071 & 5764 & 6152 & 7241 \\
\hline 틉 4/ & 5973 & 5807 & 5468 & 6273 & 6208 & 6474 & 6334 & 5651 & 5586 & 5973 & 7241 \\
\hline Negotino & 353 & 56 & 150 & 0 & 0 & 0 & 234 & 421 & 119 & 178 & 0 \\
\hline Imports & 355 & 540 & 1010 & 1053 & 1228 & 1651 & 1950 & 2618 & 2757 & 1518 & 776 \\
\hline
\end{tabular}

source: MEPSO

$1 /$ information not available beyond 2005

2/ technical losses refer to transmission losses on the low -cvoltage distribution netw ork

3/ Grid losses refer to transmission losses on the high-voltage netw ork

4/ ESM before 2006, when the company w as split up into separate generation, transmisssion, and distribution companies.

5/ 2010 full-year estimate based on Jan-Jul data and 2009 monthly pattern

Electricity demand is dominated by large industrial users and households. The 10 largest industrial customers are mainly found in the metals and mining sectors. These largest industrial users amounted for some 25 percent of total electricity consumption in 2005-08. Households, meanwhile, consumed around 50 percent of total, and together with small industry and SMEs consumption of these regulated consumers reached around 72 percent of total (including over 15 percentage points in technical losses and theft). Transmission (grid) losses accounted for the remainder. These percentages have shown a gradual trend of an increasing share of electricity usage by heavy industry, and a concomitant decrease in relative share of households. In 2009, however, the trend was reversed: as metal exports collapsed, heavy industry used only 17 percent of total electricity in 2009, while regulated consumers (households, small industry and SMEs) together consumed 80 percent.

Domestic electricity supply is mainly from thermal and hydro generation. The main domestic generation facilities are the lignite-fired thermal power plants in Bitola and Oslomej (together $800 \mathrm{MW}$ ), with the three generation blocks at Bitola alone representing 675MW. Both these generation facilities are owned and operated by the state-owned ELEM (ELEktrani na Makedonija, or Electric Power Stations of Macedonia). In addition, there is a back-up thermal power plant fueled by heavy fuel oil in Negotino (210 MW capacity), which is not owned by ELEM. Hydroelectric generation represents the other main domestic electricity supply, with a total installed capacity amounting to $528 \mathrm{MW}$, out of which over $500 \mathrm{MW}$ is run by ELEM. As power plants, and in particular hydro power plants due to their dependence on hydrological conditions, cannot continuously be run at peak capacity, overall electricity generated by hydro facilities amounts to some 20 percent of total. Further modest domestic generation capacity exists in geothermal, while there are plans for small wind farms also.

Domestic generation capacity does not suffice to meet demand. Generation capacity has to match peak demand plus a reasonable amount of spare capacity to ensure room for failure and maintenance of equipment. With peak demand in Macedonia at some 1,500 MWh, and hydro generation limited by water supply, it is clear that domestic generation capacity is insufficient to supply the market. The difference between demand and supply is made up by electricity imports through the high-voltage international transmission network. Total imports 
averaged 20 percent of demand (1,468 GWh) between 2000 and 2009, and peaked at 32 percent of demand (2,757 GWh) in 2008, the year before the global crisis impacted Macedonian power demand in earnest.

Electricity generation fall shorts of EU environmental standards and its output is used inefficiently. The domestic thermal generation facilities heavily rely on dirty lignite for fuel, and as a consequence they are dirty by international comparison. The main facility at Bitola, for instance, operates on lignite, and emits much $\mathrm{CO}_{2}$, as well as $\mathrm{NO}_{\mathrm{x}}$ (exceeding the limits set in the EU Large Combustion Plants Directive about 4 times), and $\mathrm{SO}_{\mathrm{x}}$ (exceeding the LCP Directive limits about 7-8 times). ${ }^{2}$ Total $\mathrm{CO}_{2}$ emission in Macedonia amount to some 14.4 Megaton $\mathrm{CO}_{2}$-equivalent (about 7.2 tons per capita), of which the thermal generation accounts for some 70 percent. ${ }^{3}$ This implies emissions which are 60 percent higher per unit of GDP than the OECD average. ${ }^{4}$ In turn, this is an indication of both inefficient usage and inefficient generation facilities.

Both the dirty generation and the inefficient usage of electricity stem from past policy choices, and will take time to change. The Bitola thermal power plant, as well as many of the main industrial electricity-using factories, was built before Macedonia became an independent country. Concerns about self-sufficiency and direct generation costs at the time trumped environmental and efficiency considerations. Since then, the low, subsidized electricity price has not provided the proper incentives to invest in energy conservation.

\section{B. Market Structure}

The Macedonia electricity market currently consists of three separate segments of endusers: The households, which are connected to the low-voltage grids, and pay a regulated price; the companies which are on the low-voltage grid (small industry and SMEs) and pay the same regulated price as the households; and the 10 largest electricity users in the country, which are directly connected to the high-voltage grid and operate on a liberalized market as of September 2008. The customers paying the regulated price are referred to as tariff customers, while the customers on the liberalized market are referred to as eligible customers.

The liberalized market for the largest users in effect drove these users to secure their supply through electricity imports. After amendments to the Energy Law came in to effect in September 2008, the 10 largest electricity users in the country have had to secure their own electricity supply. They secure their supply through electricity traders. Most of the time, there is a shortage of domestic supply, which is provided at below (regional) market rates to

\footnotetext{
${ }^{2}$ Source: ELEM

${ }^{3}$ Data for the year 2000, quoted from MANU (2010).

${ }^{4}$ Source: IEA (2009), based on the amount of $\mathrm{CO}_{2}$ emissions per unit of GDP, measured at purchasing power parity. When measured at market exchange rates, Macedonia emits 5 times as much as the OECD average per unit of GDP.
} 
tariff customers. In effect, this has forced the large users to start to import their own electricity supply from the regional market. However, during time periods when domestic supply exceeds demand by regulated customers, the traders also buy domestically produced electricity. In addition to the price the large users agree with the traders, they pay a regulated transmission fee to MEPSO (Makedonski Elektro Prenosen Sistem Operator, or Macedonian Electricity Transmission System Operator), which operates the domestic transmission network. ${ }^{5}$

The market for tariff customers has been partly unbundled, with generation, transmission, and distribution split between three separate regulated monopolies. ELEM is the regulated generator of electricity and monopoly wholesale supplier for retail distributor EVN. In case ELEM itself does not generate enough electricity to supply all tariff customers, it imports additional power. MEPSO is the sole operator of the electricity transmission network. ${ }^{6} \mathrm{EVN}$ is the retail distributor, i.e., the supplier of tariff customers. EVN buys transmission services from MEPSO and power from ELEM. EVN concludes individual contracts with retail end-users and collects payments. Prices of the services these three market parties provide, as well as end-user prices for tariff customers, are regulated by the Energy Regulatory Commission (ERC). While ELEM and MEPSO remain state-owned, the retail distributor was privatized and subsequently sold to EVN Austria in April 2006.

\section{Plans for the Future}

In the medium to long term, the authorities are planning to expand hydro generation capacity. According to the Strategy for Energy Development (MANU, 2010), existing and new renewables could contribute up to 4,600 GWh by 2030, 90 percent of which would come from hydro. The economics of some of the proposed hydro generation plants are not always compelling. Based on a 7 percent return on investment, the Strategy calculates that the cost per KWh for hydro would be in the range of 3.0-8.2 $€$ cents, while lignite comes out at 4.0 cents and gas-fired cogeneration combined heat and power (CHP) plants would generate for 5.7 cents per KWh. ${ }^{7}$ A higher discount rate, which could be warranted given the need for foreign investment and considering the country risk ${ }^{8}$, would result in higher costs for

\footnotetext{
${ }^{5}$ The price the traders charge includes transmission fees to the Macedonian border (or another contractually specified delivery point).

${ }^{6}$ The transmission network consist of the high-voltage international interconnector lines and (mainly highvoltage) power lines connecting power generation facilities with substations. The network between the substations and the end-users is called the distribution network, and is operated by EVN.

${ }^{7}$ The range for hydro generation is particularly wide, as it represents different hydro power plants, facing different hydrological and geological conditions. Within this range, only the smallest one (Lukovo Pole and Crn Kamen, $8 \mathrm{MW}$ ) is estimated to generate at a cost below 4 cents, while only one additional medium-sized plant (Boshkov Most, $68 \mathrm{MW}$ ) is estimated to be able to generate at a cost below 5.7 cents.

${ }^{8}$ The country’s 2009 Eurobond carried an interest rate of 9.875 percent. This provides a benchmark rate for foreign investment. While the bond trade at much lower yields in the secondary market, calculating with a 7 percent return seems to be on the low side.
} 
all types of generation plants. But the costs for hydro plants would increase proportionally more, because they are very capital intensive and take a long time to build. Hence, in economic terms, hydro would be further disadvantaged vis-à-vis other sources. Note that these calculations do not take account of a price for carbon emissions. A positive carbon price, which will become reality once Macedonia joins the EU Emission Trading Scheme, will benefit hydroelectricity vis-à-vis non-renewable source of generation, and in particular compared to lignite. A further consideration that should be taken on board lies in the EU's renewable target of 20 percent of total consumption, and Macedonia's own renewable energy target of 21 percent of total consumption by 2020 (Ministry of Economy, 2010). Investment in hydro generation could be justified on these grounds.

\section{The largest hydro project currently under tender is for two dams at Cebren and} Galiste. This project would comprise a total investment of around $€ 700$ million, and would add net generation capacity of 320-420 GWh. ${ }^{9}$ The tender is for investment in building, maintaining, and exploiting the dams in a joint-venture with ELEM. While several large European energy companies expressed preliminary interest in the tender, the fourth tender closed without bids in November 2010. The authorities plan to re-launch the tender in early 2011. Apart from the pure economics of the project, attracting foreign investment on this scale will also call for more general improvements in the business climate, including the judiciary. Preparations for several other, smaller, hydro concessions are also under way, including projects in Boskov Most (68 MW, €83 million), Lukovo Pole and Crn Kamen (8 MW, €53 million), and Gradec (55 MW, €203 million).

The authorities are also seeking to lower cost and safeguard supply by improving regional interconnections. The government is seeking to alleviate bottlenecks in the high voltage transmission lines by building additional international interconnection capacity. This could both reduce the cost of importing power, as well as play a role in safeguarding supply in case of unexpected event or maintenance, as in a regionally connected network, one can to some extent rely on spare capacity elsewhere in the network.

\section{EUROPEAN INTEGRATION IS DRIVING ELECTRICITY REFORM}

Macedonia has committed to gradual adoption of the EU energy policy. The goal of this policy is to secure reliable and affordable supply of energy for countries in South Eastern Europe (SEE), while safeguarding the environment. These goals and the steps toward it were formalized in the Energy Community Treaty (ECT). The treaty set up the Energy Community, which extends the EU internal energy market to South East Europe and beyond, based on a legally binding framework.

The ECT commits the signatories to implement the relevant $\mathrm{EU}$ acquis communautaire (the acquis). In particular, the contracting parties are to establish an integrated market in

\footnotetext{
${ }^{9}$ The project would include pumping water back into the reservoir in off-peak periods to be used during peak demand. While this entails an efficiency loss, it can make economic sense when the price difference between peak and off-peak power is large enough. Nevertheless, it considerably reduces the plant's net generation capacity. The estimated total investment cost includes interest during construction.
} 
natural gas and electricity. They aim to set up a single regional stable regulatory and market framework capable of attracting investment in transmission networks and generation capacity, and fostering competition and interconnectivity, thus ensuring supply and realizing economies of scale. At the same time, the treaty parties strive to decrease the environmental impact of natural gas and electricity provision, in particular through boosting efficiency and using renewable sources of energy. A fixed time frame (2015) is set for the adoption of the acquis, and the implementation process is backed up by a dispute settlement procedure, thus contributing to the enforcement of the ECT legal framework.

Since signing the ECT, the authorities have advanced steadily towards meeting their commitments. On the institutional side, an Energy Law was adopted in 2006, and amended in 2008. This law is currently being comprehensively overhauled (see below). The energy law lays out the framework for the unbundling of generation, transmission, and distribution. This has led to the current market structure (described in Section II.B). The 2006 law also provides the legal framework for the establishment and operation of the Energy Regulatory Commission (ERC - the market regulator. The ERC has since been set up in accordance with the law. It is a statutorily independent regulatory body that reports directly to parliament, with authority to monitor the energy market operations; set regulated prices; be the licensing authority; and participate in dispute resolution between market participants. The 2008 amendments to the Law created the liberalized market for the 10 largest industrial electricity users.

The authorities are currently working to solve several outstanding treaty obligations. Specifically, outstanding issues remain on market structure, cost reflectivity, and the deadline for liberalization of the nonhousehold market.

- $\quad$ Market structure. The main issue remains the dominant market position of ELEM with respect to tariff customers. For these customers, ELEM remains the monopoly wholesale generator and importer. The ECT requires imports and generation to be fully liberalized.

- Cost reflectivity. Currently, regulated prices are set in such a way that they do not incorporate certain legitimate costs, such as full technical and commercial losses (electricity theft), and certain collection shortfalls. According to the treaty obligations, prices should reflect these costs.

- $\quad$ Liberalization deadlines. While the government remains committed to the 2015 deadline for full liberalization of the entire market, it has missed the January 1, 2008 deadline for liberalization of the nonhousehold market. So far, it has only liberalized the market for the 10 largest electricity consumers in the country (see above).

To remedy these shortcomings, the ministry of economy has prepared a new Energy Law, together with secondary legislation. The law was approved by the government and sent to parliament in October 2010, but was withdrawn in November. A new drafts of the Law, including some of the numerous amendments filed in parliament and further changes, is currently (December 2010) in parliament, which is expected to adopt it soon. A preliminary analysis of the new proposed law, and discussions with the authorities, indicate that the law 
would bring Macedonia into compliance with its treaty obligations. Specifically, the legislative package will address the three outstanding issues of market structure, cost reflectivity, and liberalization deadlines mentioned above:

- $\quad$ Market structure. The law will abolish the monopoly position of ELEM on imports for tariff customers. At the same time, the law will strengthen the monitoring and enforcement role of the ERC. Such a strengthened role for the ERC would facilitate its role in bringing together supply and demand.

- Cost reflectivity. The amended rulebook for the energy market would set the rules in this market structure, taking into account that the market will only be fully liberalized by 2015. It would clarify the provisions on technical and commercial losses, as well as collection shortfalls. The rulebook amendments have to be made by the ERC. It, however, is awaiting the new energy law before proceeding with such amendments.

- Deadlines. The law or secondary legislation would clarify the time line for liberalization of the non-household sector (2012) and household sectors (2015).

Furthermore, together with the Energy law, the authorities have introduced measures for social protection of vulnerable households in a liberalized market. Given the relatively low electricity price, market liberalization will result in substantial price increases. While desirable from the perspective of eliminating subsidized pricing for all customers, poorer household would need to be partially protected against such price rises. Among the several ways available to provide such support, the authorities have introduced a lump-sum cash subsidy payment, targeted at the poorest households (for details, see Section IV).

\section{The ongoing legal proceedings between EVN and ELEM and the Republic of} Macedonia present another outstanding issue. EVN entered the market by buying the electricity distribution network ESM in 2006 for $€ 225$ million. ${ }^{10}$ According to EVN, the share purchase agreement specified that EVN would not be liable for uncollected receivables from before the privatization. ${ }^{11}$ Shortly after the privatization, however, ELEM interpreted the sale agreement differently, and claimed that EVN should pay the $€ 90$ million of outstanding receivables, which, including interest, led to a claim of $€ 160$ million. In the ensuing legal proceedings, the Skopje basic court found for ELEM. EVN has appealed, after which the appeals court sent the case back to the court of first instance, citing substantial procedural shortcomings in the original verdict. Meanwhile, EVN has sued the Republic of Macedonia at the World Bank's International Centre for Settlement of Investment Disputes (ICSID) for breach of several investment treaties, as well as in the London court of

\footnotetext{
10 The sale price was later reduced by $€ 22.5$ million, as the share purchase agreement specified that deviations in the balance sheet prepared under IFRS would lead to adaptation in the sale price. Negative deviations, leading to a lower equity value of the company, were indeed found by the independent auditor, leading to the ex-post sale price reduction.

${ }^{11}$ ESM had previously agreed with ELEM to aim to collect these debts. The proceeds would be split evenly between ESM and ELEM.
} 
arbitration for breach of the share purchase agreement. It reportedly claims damages of $€ 1$ billion from the Government. Currently, efforts to come to a negotiated out-of-court settlement continue. Such a solution would likely imply dropping ELEM's claim and EVN's counter claim, and clearly specifying the market conditions under which EVN will operate going forward. A solution along these lines will likely improve foreign investor perception and interest in energy sector investment in the country.

\section{SUBSIDIES ARE DECLINING}

The current market structure implies substantial implicit subsidization of electricity supply. First, the electricity price for tariff customers is regulated at a level below the regional market price, implying subsidization. Second, whenever tariff customers' demand is larger than supply, ELEM imports power for these customers, which is sold below the import price.

The electricity price for tariff customers is subsidized. Since the regulated price lies above the short-run marginal cost of generation, however, the subsidy is mostly implicit. For the electricity produced domestically, the regional market price represents the foregone opportunity benefits of selling the generated electricity at the regional market price. This market price is used to calculate implicit subsidies. Only for the part of the electricity consumption that is not generated domestically, and which hence has to be imported, does the subsidy amount to a direct out-of-pocket expense. However, part of the implicit subsidy for domestically produced electricity may still represents a true long-term cost, as the marginal generation cost of generation does not properly reflect the long-run costs of mining and depreciation. While current marginal mining cost is reflected, the main Suvudol coal mine is almost exhausted. Replacement coal deposits, while plenty, are projected to be considerably more expensive to mine. Furthermore, current generation facilities are valued at below replacement cost, and hence depreciation costs of the existing generation facilities will not suffice to replace aging facilities in the future.

These implicit subsidies are inefficient, and the authorities are committed to phasing them out. By distorting incentives, electricity subsidies stimulate usage and hence an inefficient use of scarce resources. As a social policy, electricity subsidies are inefficient, since most electricity is used by the richer households, who hence benefit from the bulk of the subsidies. In addition, keeping electricity tariffs below market clearing levels discourages domestic and foreign investment in the sector. Through the ECT, the government has committed to fully liberalize the market by 2015, implying a gradual phasing out of subsidies and rising end-user prices. At current tariff and market prices, this would require an almost 40 percent tariff increase over the next five years. Rising prices should be accompanies by increases in the targeted social assistance available to poorer households, in order to keep a limited supply of electricity for basic and essential needs affordable for these households.

The total amounts involved in these subsidies is estimated at about 2.3 percent of GDP in 2009, or $€ 150$ million. This estimate is based on a regional market price of $€ 63$ per $\mathrm{MWh}$ (ELEM's average weighted import price in 2009), while the price at which ELEM supplies tariff customers is equivalent to some $€ 30$ per MWh. In addition, calculating the implicit subsidy takes account of the average transmission price of $€ 4$ per $\mathrm{MWh}$, which is included in 
the import price of $€ 63$ per MWh but should not be included when calculating the opportunity costs, as this revenue would not accrue to the generator. Multiplying the price difference with volume consumed by tariff customers in 2009 yields the above cost estimate (Table 2). ${ }^{12}$ Assuming that the regional market price includes the full cost of generation, i.e., including the full cost of mining and depreciation, this cost estimate reflects the full implicit subsidy.

Out of this total subsidy, providing subsidized imports to tariff customers costs some $\mathbf{0 . 2}$ percent of GDP or $€ 12$ million in $2009 .{ }^{13}$ Whenever generation capacity falls short, ELEM imports additional electricity, which is subsequently sold to tariff customers at the regulated price. The cost involved can hence be calculated by multiplying the price difference between the regulated price and the volume-weighted average import price with the imported volume (Table 2). This subsidy shows up in state-owned ELEM's accounts as a loss, and is cross-subsidized with profits from other activities.

Table 2. FYR Macedonia: Subsidies and Losses in the Electricity Sector, 2008 - 2010

\begin{tabular}{|c|c|c|c|c|c|c|c|}
\hline & \multicolumn{2}{|c|}{ Quantity (MWh) } & \multicolumn{2}{|c|}{ Price (euro per MWh) 4/ } & \multicolumn{3}{|c|}{ Cost (percent of GDP) } \\
\hline & 2009 & 2010 & 2009 & 2010 & 2008 & 2009 & 2010 \\
\hline Pricing subsidies $1 /$ & $5,230,050$ & $5,334,651$ & $63-30-4=29$ & $46-33-4=9$ & 3.8 & 2.3 & 0.7 \\
\hline of which: subsidized imports & 370,166 & - & $63-30=33$ & $46-33=13$ & $\mathrm{n} / \mathrm{a}$ & 0.2 & 0.0 \\
\hline Excess distribution losses 2/ & 754,334 & 583,842 & 30 & 33 & 0.3 & 0.4 & 0.3 \\
\hline Collection shortfall $3 /$ & 784,507 & 533,465 & 30 & 33 & 0.6 & 0.4 & 0.3 \\
\hline Total Losses & & & & & 4.7 & 3.1 & 1.3 \\
\hline
\end{tabular}

Sources: ELEM, MEPSO, Domestic Regulation, and Staff Estimates

$1 /$ The import price differential is applied to distribution consumers and excess distribution losses.

The import price is ELEM's 2009 average import price, which is assumed to be representative for the regional market.

2/ Assumes a 24, 20, and 18 percent distribution loss for for 2008, 2009, and 2010 respectively, and 11 percent distribution

losses as the international standard (as per Regulatory Commission formula).

3/ Assuming EVN's collection rate improved from 75 percent in 2008 to 85 percent in 2009 and 90 percent in 2010.

4/ The regulated domestic price at which ELEM sells its production remained at €30/MWh in 2009 and increased to €33/MWh in 2010 .

These estimates of subsidies are considerably lower than previous estimates based on 2008 prices, due to structural reform and lower energy prices. In IMF (2009), total pricing subsidies were estimated at 3.8 percent of GDP in 2008, without distinguishing between the direct and indirect subsidies. The estimate for 2009 is lower for several reasons. First, as of September 2008, the government has obliged the largest 10 electricity customers to secure their own supplies on the regional market. They hence pay the regional market price (plus a transmission and service fee), and subsidies to these customers have been eliminated. ${ }^{14}$ Second, the regional market price for electricity has decreased from an average

\footnotetext{
${ }^{12}$ In the calculation, one need to correct for recognized losses (technical and commercial losses), which are included in the generated amount of electricity but for which no payment is ever received. Recognized losses stand at 11 percent per the ERC decision.

${ }^{13}$ As this is not an opportunity cost but an actual expense, the full import price, including transmission cost, is taken into account.

${ }^{14}$ This move resulted in continuous complaints of the large consumers about an unlevel playing field due to a cost disadvantage compared to their smaller competitors, who for the moment remain tariff (subsidized) electricity consumers. Further market liberalization (see Section III) will deal with this issue by pushing all nonhousehold customers onto the liberalized market.
} 
of $€ 82$ per MWh in 2008 to $€ 63$ per MWh in $2009 .{ }^{15}$ Third, tariff prices were raised 13 percent in late 2008 (and another 10 percent at the start of 2010).

In 2010, some of these effects have reduced the pricing subsidy further to an estimated 0.7 percent of GDP (Table 2). The main contributing factor to the lower estimate for subsidies lies in the lower regional market price of $€ 46$ per MWh (the prevailing price at the start of the year, when actual imports took place), and the 10 percent increase in the regulated domestic electricity price on January 1, 2010. In addition, rainfall during the 2009-2010 winter has been plentiful, enabling ELEM to generate significantly more hydro electricity in the winter months (when consumption is high) compared to the long-run average. This has reduced the need for imports substantially, and the above estimate for 2010 assumes no imports, and hence no subsidization outlays for imports. Unfortunately, as rainfall reverts to historic averages, imports could increase again, and unless offset by price liberalization, could increase subsidy outlays. In addition, climate change studies (see, e.g., Bergant, 2006) suggest that, from a hydrological perspective, water-management and the directly associated hydro generation of electricity will become more challenging in the future. Similarly, the current low regional market price for electricity might increase again in the future when demand picks up on the back of renewed economic growth. Still, in 2010 and beyond, the large consumers will continue to operate without subsidization, which permanently lowers the amount of subsidies involved.

In addition to these subsidies, there are further losses in the system, which, however, no longer accrue (indirectly) to the state. Since the privatization of the distribution network, the unrecognized distribution losses and the collection shortfalls accrue to EVN. These unrecognized distribution and collection losses amounted to a further estimated 0.8 and 0.6 percent of GDP in 2009 and 2010 respectively (Table 2). These estimates assume moderate improvement over time in distribution losses and collection shortfalls, as bringing down these losses has been one of the main areas of focus and investment of EVN. ${ }^{16}$

Going forward, with unchanged policies, the pricing subsidies will remain roughly constant as a share of GDP in the future while the excess distribution losses and collection shortfalls will decrease moderately. Estimates for 2015, assuming no imports, indicate that the quasi-fiscal subsidies will decrease to some 0.5 percent of GDP (Table 3 , Baseline). On unchanged policies, excess distribution losses and collection shortfalls will decrease moderately to 0.6 percent of GDP. ${ }^{17}$ The estimates are based on the assumption of

${ }^{15}$ During the year 2009, the price decreased almost continuously to about $€ 46$ per MWh in December. However, the largest monthly volumes of imports were realized in the first few months of the year, when the import prices were still considerably higher.

\footnotetext{
${ }^{16}$ No recent data was made available by EVN. Based on discussion with industry experts, I assume 20 percent total distribution loss and an 85 percent collection rate for 2009.

${ }^{17}$ As above, these estimates are based on assumed improvements in distribution losses and collection shortfalls. I calculate with distribution losses of 18 and 16 percent for 2010 and 2015 respectively, and collection rates of 90 percent for 2010 and beyond.
} 
domestic price increases of 10 percent per year, increases in transmission costs in line with inflation, regional market prices in line with the 2003-09 average (plus inflation), and consumption increases equivalent to the real GDP growth rate.

Table 3. FYR Macedonia: Subsidies and Losses in the Electricity Sector, Scenarios for 2015

\begin{tabular}{|c|c|c|c|c|c|c|c|c|c|c|}
\hline \multirow[b]{4}{*}{ Pricing Subsidies $1 /$} & \multicolumn{2}{|c|}{ Quantity (MWh) } & \multicolumn{4}{|c|}{ Price (euro per MWh) } & \multicolumn{4}{|c|}{ Cost (Percent of GDP) } \\
\hline & \multirow[t]{2}{*}{2010} & \multirow{2}{*}{$\begin{array}{c}2015 \\
\text { Baseline }\end{array}$} & \multirow[t]{2}{*}{2010} & \multicolumn{3}{|c|}{2015} & \multirow[t]{2}{*}{2010} & \multicolumn{3}{|c|}{2015} \\
\hline & & & & Baseline & Scenario 1 & $\overline{\text { Scenario } 2}$ & & Baseline & Scenario & Scenario 2 \\
\hline & $5,334,651$ & $6,490,418$ & $46-33-4=9$ & $65-53-5=7$ & $65-42-5=18$ & $58-53-5=0$ & 0.7 & 0.5 & 1.2 & 0.0 \\
\hline Excess distribution losses 2/ & 583,842 & 495,301 & 33 & 53 & 42 & 53 & 0.3 & 0.3 & 0.2 & 0.3 \\
\hline Collection shortfall $3 /$ & 533,465 & 649,042 & 33 & 53 & 42 & 53 & 0.3 & 0.4 & 0.3 & 0.4 \\
\hline Total Losses & & & & & & & 1.3 & 1.1 & 1.8 & 0.7 \\
\hline
\end{tabular}

Source: ELEM, MEPSO, Domestic Regulation, and Staff Estimates

$1 /$ The import price differential applied to distribution consumers and excess distribution losses.

The import price for 2015 is based on the average import price 2003-09, increased by inflation

2/ Assumes an 18 and 16 percent distribution loss for for 2010 and 2015 respectively, and 11 percent distribution

losses as the international standard (as per Regulatory Commission formula).

3/ Assuming EVN's collection rate remains at 90 percent after 2010.

\section{The estimates are roughly linear in the assumptions on future price increases and} import prices. For instance, a 5 percent annual domestic price increase from 2011 to 2015 (instead of the assumed 10 percent), would increase the estimated pricing subsidization from 0.5 to 1.2 percent of GDP (2015 - Scenario 1), while a 10 percent lower average import price would reduce the estimate to almost 0 percent of GDP (2015 - Scenario 2). Such a lower average import price might be realized through the authorities' plans to increase high-voltage international transmission capacity. In the long-run, this wills presumable close some of the price differential between the regional market price and the market price in Western Europe.

\section{In addition to the pricing subsidies, the government introduced a targeted social} assistance package for poor households. From September 2010 onwards, an estimated 58,000 families became eligible for social assistance for heating in the amount of $€ 10$ per month per household, which would provide for about $200 \mathrm{KWh} .{ }^{18}$ While a lump-sum subsidy, it is targeted at combating the effects of electricity price increases for poor households. Electricity prices have increased by 10 percent this year, and future further substantive increases are likely. The fact that many households use electricity as one of the means to heat their home during winter makes this kind of social assistance all the more necessary. ${ }^{19}$ The total maximum estimated cost of $€ 7$ million ( $€ 10 * 12$ month $* 58,000$ households), or 0.1 percent of GDP, is modest, and the assistance is well-targeted. ${ }^{20}$ Going

\footnotetext{
${ }^{18}$ Based on an average residential price of MKD 3.34/KWh (day) and MKD 1.67/KWh (night). Both rates do not include the regular additional fee for transmission and spare capacity. This fee is, however, taken into account in these calculations.

${ }^{19}$ The subsidy, in fact, also applies to other expenditures for heating. I.e., a poor household can ask for payment of the full subsidy in case its total heating bill (electricity + district heating + fuel oil + firewood) is above $€$ 10 per month.
} 
forward, this assistance might have to be increased in line with future price increases. Still, the efficient targeting ensures that the social subsidy is kept at the minimum amount needed to achieve its goal of assistance to poor households.

Reducing pricing subsidies over the coming years will require commitment to implement fully the government's target of full price liberalization. If prices are liberalized fully by 2015, as called for under the new Energy Law, this will eliminate pricing subsidies. Achieving this will require strong political will, in particular if international prices rise from current levels, which would require higher domestic price increases. In this context, the government's new targeted lump-sum social benefit for heating expenses will cushion the effects of electricity price increases for poor households and should increase social acceptance of price increases.

\section{LONGer Term Outlook ANd Policy OPTIONS}

Several significant longer term risks are present in the outlook for the region. The longer term outlook for the wider region of Central, Eastern, and Southeastern Europe (CESE) together with Central Asia includes significant risks. On current policies, electricity supply is likely to decline over the next two decades. Many electricity generation and district heating facilities are ageing, which means that they will have to shut down or will at the very least operate less efficiently. At the same time, on the back of economic growth, demand for energy in the region is projected to increase significantly.

A regional mismatch between supply and demand is projected to create a squeeze in the regional electricity market. As electricity does not lend itself well to long-distance export, the market is of a regional nature, i.e., the western Balkans. On current trends, investment in new generation facilities is not making up for the losses from ageing facilities, likely resulting in decreased regional supply. At the same time, while the CESE economies recover from the crisis and return to growth around potential, demand for electricity will increase significantly. Even when incentives to increase energy efficiency are put in place, and hence the energy intensity per unit of GDP will decrease, total electricity consumption is projected to increase by 3.1 percent a year on average, or over 100 percent over 2005 levels by 2030 (World Bank, 2010).

Early and decisive policy action can diminish the effects of such a squeeze or possibly even prevent it all together. Policy actions include options on the supply as well as on the demand side. On the supply side, attracting large private sector energy firms to invest in generation capacity is part of the solution. In addition, investment in the international highvoltage transmission network will ensure that Macedonia can also benefit to the full extent of investment in generation made outside its borders. On the demand side, energy efficiency

\footnotetext{
${ }^{20}$ Other options for social assistance, such as, e.g., a social tariff up to a usage threshold, are less efficient, in the sense that they provide a subsidy to all households, rather than just the poor households. The cost estimate is a maximum, as poor household will have to apply and show proof of payment before being eligible to receive the subsidy.
} 
needs to be promoted. At the same time, incentives need to be devised and implemented to stimulate environmentally friendly solutions. Establishing a carbon price in line with the European carbon trading scheme would provide a market-friendly way toward this goal.

On the supply side, authorities need to provide an enabling environment for private sector investment. This applies to investment in new generation capacity, and could also include the privatization of existing capacity. The public sector does not have the resources to finance all the necessary investment in energy infrastructure. Moreover, private companies can bring in valuable knowledge and expertise on how to run large generation facilities profitably and efficiently. Hence, it is essential that countries in the region put in place incentives for private sector investment. The main elements of such an investment environment should be geared towards reducing uncertainty for investors, and would include:

- $\quad$ Setting out a clear multi-year time frame for market liberalization, as envisaged in the new Energy Law, and sticking to it. A clear time frame for market liberalization reduces the uncertainty of potential returns on large, long-term investments in generation capacity. Lower uncertainty makes investment more attractive, and enlarges the pool of profitable investments.

- $\quad$ Providing a stable and predictable legal and regulatory environment, as perceived in the new Energy Law. Clear rules and regulation, and a regulator that is independent both on paper and in practice, further reduce uncertainty. Full adoption of the EU acquis on energy, as envisaged in the Energy Law, would go a long way toward achieving such stability.

- Improving the environment for collection and lower theft. Improved cooperation between the energy suppliers, the judiciary, and in some cases the police, could lead to better enforcement of payment discipline, and lower the amount of electricity theft.

- Working with other countries in the region to strengthen regional security of supply. Individual markets in the region are mostly small to realize the full efficiencies of scale of large energy investments. The establishment of a transparent regional market, including sufficient interconnection capacity (and nondiscriminatory access to such capacity), would ensure that such efficiencies can be realized, and would hence enhance the scope for profitable investment. At the same time, it would increase the security of supply, by providing a regional network of backup facilities.

On the demand side, energy efficiency should become a policy priority. The Government's recent Energy Strategy (MANU, 2010) and Renewable Energy Strategy (Ministry of Economy, 2010) clearly spell out these issues and set policy priorities to achieve a higher level of energy efficiency. Several short and medium-term option come to mind in particular:

- $\quad$ Promoting better insulation of businesses and homes. Premises are often heated using electricity. Better insulation will hence reduce electricity demand. Higher electricity prices, in line with the regional market price, will provide an incentive. 
Additionally, transparent marking of energy efficiency of products, mandating energy efficiency standards, and promoting the most energy-efficient products could be part of the policy mix.

- Gasification of the country and the use of gas-fired cogeneration plants (which produce both electricity and heat) could reduce electricity as a source of heating. Such efforts should not be limited to electricity usage only. For instance, consumers should be given better control over the amount of district heat they consume. ${ }^{21}$

Implementing these policy options, as envisaged by the authorities, will have further positive effects beyond boosting supply and containing demand. Specifically, policy measures can reduce both the import bill as well as the amount of subsidization.

- $\quad$ First, full market liberalization will reduce subsidies. As a first step, all nonhousehold customers will be pushed onto the liberalized market in 2012, where they would have to pay the full market price for power. This will be followed by liberalization of the market for household customers by 2015. As this will likely go hand in hand with increased subsidies to poorer households for basic electricity usage, direct subsidies would not be totally eliminated, but reduced to a minimum. In addition, the subsidies would be more visible, enhancing transparency.

- Second, investment in generation capacity would reduce the import bill, benefit the environment, and likely contribute to knowledge transfer. While reduction of the import bill should not be a policy goal in itself, a lower current account deficit, which would, ceteris paribus, be the result of lower imports, would reduce external vulnerabilities. New investment in modern generation technology would also benefit the environment. Modern facilities are more efficient and hence generate lower emissions per unit of output. Switching from lignite to other, cleaner, fuels, such as natural gas in co-generation plant, would yield further environmental benefits. In addition, there is potential for investments in renewables, in particular in hydro generation. To the extent that new investment will include sizeable FDI, foreign investors would also bring in knowledge, both on the technical side, as well as on project management.

Several of the policy directions outlined above are currently awaiting implementation. As detailed above, the authorities are committed to adopt the EU acquis on energy under the ECT, which implies fully liberalizing the electricity market. The new Energy Law, and concomitant new rulebook for the energy market, which the regulatory commission is expected to start preparing soon, will lay down the new market structure and the details of the rules under which the market operates. Full and consistent implementation of these rules will ensure the predictability of the regulatory environment.

\footnotetext{
${ }^{21}$ At the moment, district heat is provided at a uniform temperature set by the provider, and can be either turned on or off by the user. Thermostatic valves would enable consumers to heat to a specific individually chosen preset temperature.
} 
Going forward, implementation of these policies will improve the foundations for sustained growth. The policies will bring regulation of the electricity sector up to European standards, will contribute to reliable and safe energy supply at lower environmental costs, with transparent and cost-effective social subsidies, and reduce risks to the balance of payments and the budget. They will hence provide some of the necessary pre-conditions for economic growth. 


\section{REFERENCES}

Bergant, K, 2006, “Climate Change Scenarios for Macedonia,” Report for the United Nations Framework Convention on Climate Change, University of Nova Gorica: Nova Gorica, Slovenia.

Energy Community Secretariat, 2009, "Report on the Implementation of the Acquis under the Treaty Establishing the Energy Community,” available from http://www.energycommunity.org/portal/page/portal/ENC_HOME/DOCUMENTS?library.category=15 $\underline{7}$

European Commission, 2006, "Commission decision amending the Annex to Regulation (EC) No 1228/2003 on conditions for access to the network for cross-border exchanges in electricity,” Official Journal of the European Union L 312/59, Brussels.

EU Council, 2004, "Council directive 2004/67/EC concerning measures to safeguard security of natural gas supply,” Official Journal of the European Union, L127/92, Brussels.

European Parliament and EU Council, 2003a, “Directive 2003/54/EC of the European Parliament and of the Council concerning common rules for the internal market in electricity and repealing Directive 96/92/EC,” Official Journal of the European Union L176/23, Brussels.

European Parliament and EU Council, 2003b, “Regulation (EC) No 1228/2004 of the European Parliament and of the Council on conditions for access to the network for cross-border exchanges in electricity,” Official Journal of the European Union, L176/1, Brussels.

European Parliament and EU Council, 2003c, “Directive 2003/55/EC of the European Parliament and of the Council concerning common rules for the internal market in natural gas and repealing Directive 98/30/EC," Official Journal of the European Union L176/57, Brussels.

European Parliament and EU Council, 2005, “Regulation No 1775/2005 of the European Parliament and of the Council on conditions for access to the natural gas transmission networks,” Official Journal of the European Union L289/1, Brussels.

European Parliament and EU Council, 2006a, "Directive 2005/89/EC of the European Parliament and of the Council concerning measures to safeguard security of electricity supply and infrastructure investment,” Official Journal of the European Union L33/22, Brussels.

European Parliament and EU Council, 2009, "Proposal for a Regulation of the European Parliament and of the Council concerning measures to safeguard security of gas supply and repealing Directive 2004/67/EC,” mimeo.

International Energy Agency, 2009, “CO를 Emissions from Fuel Combustion - Highlights,” 2009 Edition, OECD/IEA: Paris. 
International Monetary Fund, 2009, "Former Yugoslav Republic of Macedonia: Selected Issues,” IMF Country Report 09/61, International Monetary Fund: Washington, D.C.

MANU, 2010, "Strategy for Energy Development in the Republic of Macedonia until 2030," Macedonian Academy of Sciences and Arts: Skopje, Macedonia.

Ministry of Economy, 2010, "Strategy for the Use of Renewable Energy in the Republic of Macedonia by 2020,” Ministry of Economy: Skopje, Macedonia.

World Bank, 2010, "Lights Out? The Outlook for Energy in Eastern Europe and the Former Soviet Union,” The World Bank: Washington, D.C. 